\title{
Hybridization behaviour between two common European cyprinid fish species - silver bream, Blicca bjoerkna and common bream, Abramis brama - in a controlled environment
}

\author{
Billy Nzau Matondo ${ }^{1, *}$, Michaël Ovidio ${ }^{1}$, Jean-Claude Philippart ${ }^{1}$ and Pascal Poncin ${ }^{2}$ \\ ${ }^{1}$ University of Liege, Biology of Behaviour Unit, Laboratory of Fish Demography and \\ Hydroecology, 10 Chemin de la Justice, B-4500 Tihange, Belgium \\ ${ }^{2}$ University of Liège, Biology of Behaviour Unit, Laboratory of Fish Ethology, 22 Quai \\ Van Beneden, B-4020 Liège, Belgium
}

\begin{abstract}
The egg release-mating comparison, heterospecific matings and mating success under two hybridization conditions - (i) mixing one sex per species and (ii) mixing both sexes from each species - were investigated to determine whether silver bream Blicca bjoerkna and common bream Abramis brama can hybridize in nature.

The results revealed that non-matings in hybridization experiments of silver bream females $\times$ common bream males can be explained by territorial and aggressiveness activities observed in common bream. In common bream females $\times$ silver bream males, heterospecific matings were observed but their numbers were significantly lower than the spawning numbers, and in this experiment, a female mated with one to four heterospecific males. In mixing both sexes from both species, similar spawning - mating numbers were observed but heterospecific matings accounted for only $27 \%$ of the total matings, with $24 \%$ accounting for heterospecific matings between common bream females and silver bream males, directly or by opportunism. Mating success was characterized by the occurrence of fertilized eggs after matings.

Natural hybridization occurred preferentially between common bream females and silver bream males. (C) Koninklijke Brill NV, Leiden, 2009.
\end{abstract}

\section{Keywords}

Egg release - mating; heterospecific matings; mating success

\section{Introduction}

Silver bream Blicca bjoerkna L. and common bream Abramis brama L. are two common European cyprinid fish that can hybridize in rivers (Wheeler, 1969; Swinney and Coles, 1982) and in experimental conditions (Backiel and Zawiska, 1968; Nzau

\footnotetext{
*) Corresponding author; e-mail: bnzamat@yahoo.fr
} 
Matondo et al., 2007), mainly because they live in sympatry (Huet, 1949; Philippart, 1989) and have similar spawning requirements (Philippart and Vranken, 1983; Spivak, 1987; Poncin et al., 1996). Previous studies have also demonstrated that the hybrids from these species are viable and thus have the biological capacity to reproduce and to exhibit a high level of sexual activity (Nzau Matondo et al., 2008a). As a consequence, different authors have proposed to place these two species in the same genus (Freyhof, 1998; Wolter, 1999; Hänfling and Brandl, 2000; Poncin et al., 2004; Nzau Matondo et al., 2008a).

The reproductive behaviour of these two species has already been studied. It has been described as polygamous (Shestopalova, 1978; Turner, 1986; Spivak, 1987; Billard, 1997; Poncin et al., 2000) and phytophilous spawner (Gillet, 1989; Kozlovskij, 1991; Mill, 1991). In common bream, males exhibit territorial and aggressive activity (Svardson, 1949; Fabricius, 1951; Poncin et al., 1996) but in silver bream, males are nonaggressive and nonterritorial (Poncin et al., 2004; Nzau Matondo et al., 2008b). However, the ethological aspects of the hybridization process of these species remain totally unknown. Such studies would be useful to better understand how heterospecific matings occur in the natural environment.

The aim of the present study was to explore the ethological mechanisms allowing the breakdown of reproductive barriers between the two different species. Eggs release and matings comparisons, mating patterns and eyed embryos rates were analysed under hybridization experiments by mixing one sex of each species and mixing both sexes of the two species, in a controlled environment simulating natural conditions.

\section{Material and methods}

\section{Spawner collections}

Silver bream and common bream specimens used as spawners were collected from natural populations in a fish pass trap at the Lixhe dam (Belgian Meuse River, $50^{\circ} 45^{\prime} \mathrm{N}$; $5^{\circ} 40^{\prime} \mathrm{E}$ ) during their upstream reproductive migration in spring 2003 (May - June). They were morphologically identified on the basis of descriptions made by Spillman (1961), Wheeler (1969), and Maitland (2005). All spawners were mature. The selected females were gravid and males produced milt. Six females and twenty males per species were selected twice.

\section{Hybridization experiments}

Hybridization experiments were conducted in two sets of mixing conditions: (i) mixing one sex of one species with other sex of the other species, where three silver bream females were placed to reproduce with ten common bream males for experiment I and three common bream females were mixed with ten silver bream males for experiment II and (ii) mixing two sexes of the two species, where three silver bream females and ten silver bream males were mixed with three common bream females and ten common bream males for experiment III (table 1). Each experiment was duplicated. The age of 
the fish was determined by counting annuli (Ombredane and Baglinière, 1992) on scales (Philippart, 1971; Katano and Hakoyama, 1997) collected on the first two rows above the lateral line passing vertically from the anus (Philippart, 1981).

Experiments were conducted in a $1.75 \times 1.30 \times 1.20$-m experimental aquarium equipped with a $1.05 \times 0.89-\mathrm{m}$ synthetic spawning substrate simulating vegetation. The water temperature was set at $20 \pm 0.2^{\circ} \mathrm{C}$ and the fish were placed in continuous lighting conditions for recording behaviour throughout all experimental period. Dissolved oxygen was above $8 \mathrm{mg} / \mathrm{l}$. A recirculation pump created an artificial water flow in the aquarium $(21 \mathrm{~cm} / \mathrm{s})$. Fish were not fed. Spawning was induced using two injections of Ovaprim, a synthesis hormone in the females $(0.5 \mathrm{mg} / \mathrm{kg}$; time between injections, $8 \mathrm{~h}$ ) and a single injection in the males. Fish were injected the day after their capture. Hormonal injection was used to synchronize the spawning activity and to reduce experimental time in 3 days only.

\section{Table 1.}

Description of hybridization experiments and spawners used. C - common bream; $S$ - silver bream; $M$, $\widehat{\delta}$ - male; F, $q$ - female; mean and standard deviation values

\begin{tabular}{|c|c|c|c|c|c|}
\hline \multirow[b]{2}{*}{$\begin{array}{l}\text { Hybridization } \\
\text { experiments }\end{array}$} & \multirow[b]{2}{*}{ Specie } & \multirow[b]{2}{*}{ Sex } & \multicolumn{3}{|c|}{ First / second replications } \\
\hline & & & Age (years) & $\begin{array}{l}\text { Fork length } \\
(\mathrm{mm})\end{array}$ & Weight (g) \\
\hline \multicolumn{6}{|l|}{$\begin{array}{l}\text { Mixing one sex of } \\
\text { each species }\end{array}$} \\
\hline \multirow[t]{2}{*}{$\begin{array}{l}3+\mathrm{O} S \times 10 \hat{\mathrm{C}} \mathrm{C} \\
\quad \text { experiment I }\end{array}$} & $\mathrm{C}$ & $\mathrm{M}$ & $5 \pm 1 / 6 \pm 1$ & $350 \pm 23 / 391 \pm 29$ & $\begin{array}{l}723 \pm 170 / \\
1079 \pm 203\end{array}$ \\
\hline & $S$ & $\mathrm{~F}$ & $6 \pm 1 / 3 \pm 1$ & $283 \pm 32 / 222 \pm 16$ & $\begin{array}{l}532 \pm 203 / \\
237 \pm 44\end{array}$ \\
\hline \multirow[t]{2}{*}{$\begin{array}{l}3+\mathrm{C} \times 10{ }^{\wedge} \mathrm{S} \\
\quad \text { experiment } \mathrm{II}\end{array}$} & $S$ & $\mathrm{M}$ & $5 \pm 1 / 3 \pm 1$ & $233 \pm 18 / 229 \pm 26$ & $\begin{array}{l}258 \pm 61 / \\
247 \pm 61\end{array}$ \\
\hline & $\mathrm{C}$ & $\mathrm{F}$ & $5 \pm 1 / 5 \pm 1$ & $347 \pm 31 / 365 \pm 17$ & $\begin{array}{l}825 \pm 176 / \\
975 \pm 162\end{array}$ \\
\hline \multicolumn{6}{|l|}{$\begin{array}{l}\text { Mixing both sexes } \\
\text { of the } 2 \text { species }\end{array}$} \\
\hline \multicolumn{6}{|l|}{$\begin{array}{r}3 q \mathrm{~S} \times 10{ }^{\lambda} \mathrm{S} \text { and } \\
3 q \mathrm{C} \times 10{ }^{\lambda} \mathrm{C} \\
\text { experiment III }\end{array}$} \\
\hline & S & $\mathrm{M}$ & $5 \pm 1 / 3 \pm 1$ & $236 \pm 11 / 227 \pm 26$ & $\begin{array}{l}266 \pm 37 / \\
178 \pm 50\end{array}$ \\
\hline & $S$ & $\mathrm{~F}$ & $6 \pm 1 / 3 \pm 1$ & $296 \pm 35 / 227 \pm 12$ & $\begin{array}{l}576 \pm 184 / \\
238 \pm 40\end{array}$ \\
\hline & $\mathrm{C}$ & M & $5 \pm 1 / 6 \pm 1$ & $352 \pm 21 / 398 \pm 21$ & $\begin{array}{l}761 \pm 115 / \\
1113 \pm 140\end{array}$ \\
\hline & $\mathrm{C}$ & $\mathrm{F}$ & $5 \pm 1 / 5 \pm 1$ & $351 \pm 30 / 390 \pm 9$ & $\begin{array}{l}835 \pm 261 / / \\
1223 \pm 132\end{array}$ \\
\hline
\end{tabular}


The egg release-mating comparison and the males participating in the mating were analysed over 1 day from 07.00 to 18.00 hours, corresponding to the beginning and end of spawning activity, using a remote-controlled video system. Mating was defined as sexual contact between fish of the opposite sex followed by expulsion of gametes. Spawning was defined as the release of eggs by a female. Release of eggs and sperms was signalled by trembling and violent splashing movements on plant substratum. Eggs release and matings acts were counted hourly in hybridization experiment. Mating success, expressed as the percentage of eyed embryos 1 day after spawning, was evaluated under a microscope with a minimum of 90 eggs per sample collected on spawning ground and repeated twice.

\section{Data analysis}

The egg relaese - mating comparison was statistically examined using the chi square $\chi^{2}-$ test. The participation of males in matings observed hourly was analysed with the KruskalWallis $K W$-test followed by multiple paired comparisons tests using the Mann-Whitney $U$-test. The percentage of eyed embryos in hybridization experiments was compared using Fisher's exact probability FEP -test. For all statistical analyses, null hypotheses were rejected at $p<0.05$.

\section{Results}

\section{Egg release - mating comparison}

A total absence of mating activity was observed in the hybridization experiments between three silver bream females and ten common bream males. However, in experiments between three common bream females and ten silver bream males, heterospecific matings (mean value $=149$ matings) were observed but they were significantly lower $\left(\chi^{2}-\right.$ test, $\left.p<0.0001\right)$ than the egg release numbers (857 egg releases) and, in experiments mixing both sexes from each species, highly similar mating and egg release numbers were observed (fig. 1).

\section{Male participation in matings}

In hybridization experiments between three common bream females and ten silver bream males, the mating number differed significantly $(K W$ - test, $\mathrm{df}=3, \mathrm{H}=15.982$, $p=0.0011)$ among the number of participating heterospecific males. The $U$-test revealed (fig. 2) that the participation of one ( $47.7 \%$ of total matings) and two $(45.6 \%)$ heterospecific silver bream males was significantly higher $(p<0.001)$ than that of four (4\%) and three $(2.7 \%)$.

In mixing both sexes from both species, two types of matings (fig. 3), conspecific matings and heterospecific matings, accounting for $73 \%$ and $27 \%$ of the total matings, respectively, were observed. The mating number differed significantly $(K W-$ test, $\mathrm{df}=$ 23, $\mathrm{H}=80.626, p<0.0001$ ) among males and species (table 2). The conspecific matings were only observed with silver bream females in which two major mating 


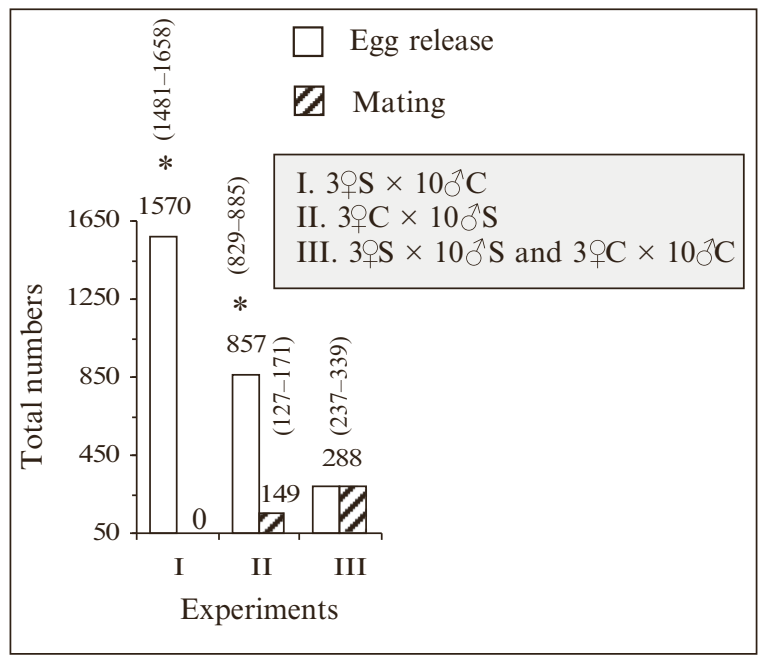

Figure 1. Egg release - mating comparisons in hybridization experiments. Shaded insert: Roman numeral, experiment number; Arabic numeral, number of fish per sex in experiment; C, common bream; S, silver bream; + , female; $\widehat{\partial}$, male. Mean and range of values of experimental duplicates above vertical bars; significant difference $\left(\chi^{2}\right.$ test, $\left.p<0.0001\right)$.

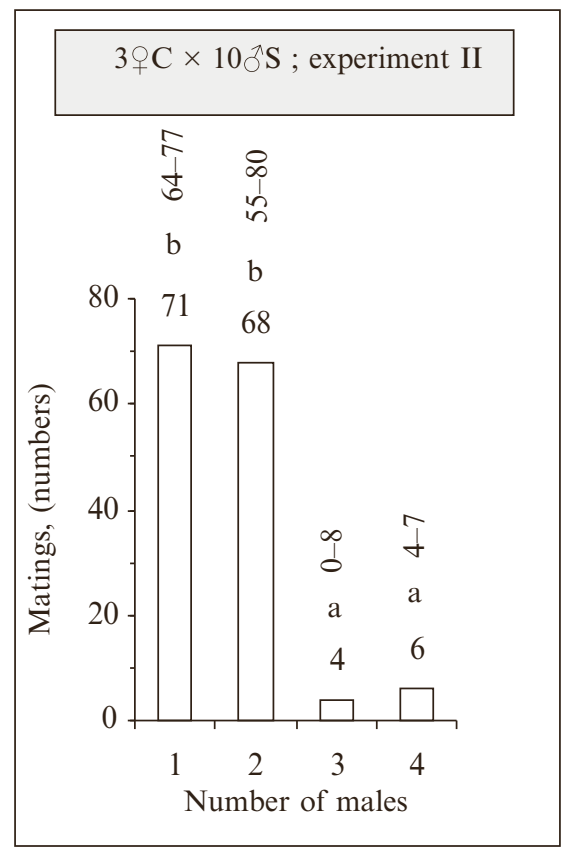

Figure 2. Males participating in mating in hybridization experiments mixing one sex of each species $\left(3+\mathrm{C} \times 10^{\lambda} \mathrm{S}\right.$; experiment II). Shaded insert: Arabic numeral, number of fish per sex in experiment; C, common bream; S, silver bream; $\$$, female; $\hat{\partial}$, male. Mean and range of values of experimental duplicates above vertical bars; Bars sharing at least one common script are not significantly different, whereas other comparisons differ at $p<0.05$ (Mann-Whitney $U$-test). 


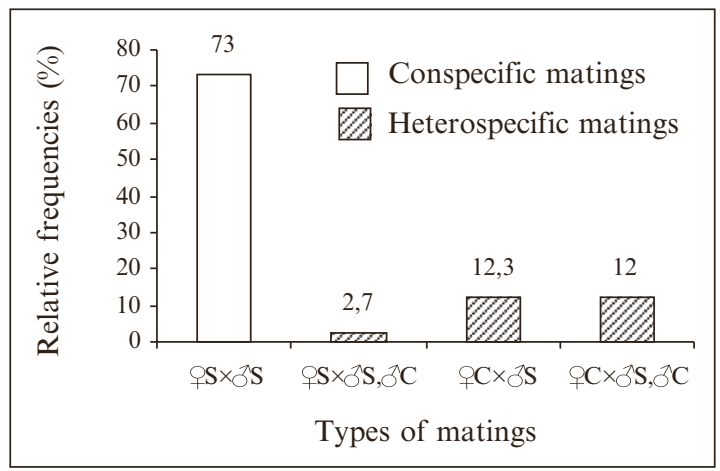

Figure 3. Relative frequencies of types of matings in hybridization experiments mixing both sexes of the

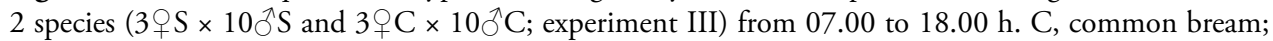
$S$, silver bream; $\hat{\partial}$, male; + , female.

combinations were observed most frequently: a silver bream female and two conspecific males (20.3\% of the total matings) and a silver bream female and four conspecific males $(30.9 \%)$. These two combinations were significantly higher than ( $U$-test, $p<$ 0.05 ) other conspecific matings and all heterospecific combinations. The heterospecific matings were observed between common bream females and silver bream males $(12.3 \%)$, common bream females with their corresponding males and silver bream males (12\%), and silver bream females with their corresponding males and the common bream males $(2.7 \%)$. In heterospecific matings, the combination between a common bream female with its corresponding male associated with six silver bream males $(8 \%)$ was observed most often.

\section{Mating success}

No eyed embryos were observed in hybridization experiments between three silver bream females and ten common bream males. The eyed embryos were observed in experiments mixing three common bream females and ten silver bream males (mean value, 20.3\%) and experiments mixing both sexes from each species (29.6\%) (fig. 4). The difference was significant between these hybridization experiments (FEP -test, $p=0.003)$.

\section{Discussion}

\section{Egg release - mating comparison}

The heterospecific matings and fertilized eggs observed in the experiments between common bream females and silver bream males revealed the absence of reproductive barriers at two different levels, pre- and post-zygotic, despite fewer heterospecific matings than egg releases and the lower survival rates of eggs than those in artificial hybridization (Nzau Matondo et al., 2007). However, our study suggests an absence of mating activity between silver bream females and common bream males that may be explained 
Table 2.

Males participating in the mating in hybridization experiments mixing both sexes of the 2 species $(3 q \mathrm{~S} \times$

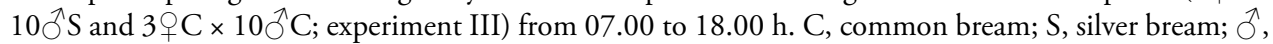
male; + , female; t, territorial male; Arabic numeral, number of fish per sex in the experiment; mean and range values of experimental duplicates. Means with a common superscript in the column do not differ significantly (U-test, $\mathrm{p}<0.05)$.

\begin{tabular}{|c|c|c|c|}
\hline \multirow{2}{*}{$\begin{array}{l}3+\mathrm{S} \times 10{ }^{\lambda} \mathrm{S} \text { and } 3+\mathrm{C} \times \\
10{ }^{\lambda} \mathrm{C} \text {; experiment III } \\
\text { Number of participating males }\end{array}$} & \multicolumn{2}{|c|}{$\begin{array}{l}\text { Matings } \\
\text { (numbers) }\end{array}$} & \multirow[b]{2}{*}{ Relative frequencies (\%) } \\
\hline & Mean & Range & \\
\hline \multicolumn{4}{|l|}{ Conspecific matings with S female } \\
\hline $1 S$ & $2.5^{\mathrm{a}}$ & $2-3$ & 0.9 \\
\hline $2 S$ & $58.5^{\mathrm{cd}}$ & $51-66$ & 20.3 \\
\hline $3 S$ & $20.5^{\mathrm{bc}}$ & $19-22$ & 7.1 \\
\hline $4 S$ & $89.0^{\mathrm{d}}$ & $82-96$ & 30.9 \\
\hline $5 S$ & $2.0^{\mathrm{a}}$ & $1-3$ & 0.7 \\
\hline $6 S$ & $31.0^{\mathrm{cd}}$ & $27-35$ & 10.8 \\
\hline $8 \mathrm{~S}$ & $6.5^{\mathrm{ab}}$ & $3-10$ & 2.3 \\
\hline \multicolumn{4}{|l|}{ Heterospecific matings with $\mathrm{C}$ female } \\
\hline $1 S$ & $4.0^{\mathrm{ab}}$ & $3-5$ & 1.4 \\
\hline $2 S$ & $9.5^{\mathrm{ab}}$ & $6-13$ & 3.3 \\
\hline $4 S$ & $5.5^{\mathrm{ab}}$ & $4-7$ & 1.9 \\
\hline $5 S$ & $0.5^{\mathrm{a}}$ & $0-1$ & 0.2 \\
\hline $6 S$ & $15.5^{\mathrm{ab}}$ & $10-21$ & 5.3 \\
\hline $7 S$ & $0.5^{\mathrm{a}}$ & $0-1$ & 0.2 \\
\hline $1 \mathrm{C}_{\mathrm{t}}+2 \mathrm{~S}$ & $0.5^{\mathrm{a}}$ & $0-1$ & 0.2 \\
\hline $1 \mathrm{C}_{\mathrm{t}}+3 \mathrm{~S}$ & $0.5^{\mathrm{a}}$ & $0-1$ & 0.2 \\
\hline $1 \mathrm{C}_{\mathrm{t}}+4 \mathrm{~S}$ & $2.5^{\mathrm{ab}}$ & $1-4$ & 0.9 \\
\hline $1 \mathrm{C}_{\mathrm{t}}+5 \mathrm{~S}$ & $3.5^{\mathrm{ab}}$ & $2-5$ & 1.1 \\
\hline $1 C_{t}+6 S$ & $23.0^{c}$ & $19-27$ & 8.0 \\
\hline $1 C_{t}+1 C+6 S$ & $2.5^{\mathrm{ab}}$ & $0-5$ & 0.9 \\
\hline $1 \mathrm{C}+4 \mathrm{~S}$ & $1.5^{\mathrm{ab}}$ & $1-2$ & 0.5 \\
\hline $1 \mathrm{C}+6 \mathrm{~S}$ & $0.5^{\mathrm{a}}$ & $0-1$ & 0.2 \\
\hline \multicolumn{4}{|l|}{ Heterospecific matings with $S$ female } \\
\hline $1 \mathrm{C}_{\mathrm{t}}+4 \mathrm{~S}$ & $5.0^{\mathrm{ab}}$ & $4-6$ & 1.7 \\
\hline $1 \mathrm{C}_{\mathrm{t}}+5 \mathrm{~S}$ & $1.5^{\mathrm{a}}$ & $1-2$ & 0.5 \\
\hline $1 C_{t}+2 C+6 S$ & $1.5^{\mathrm{a}}$ & $1-2$ & 0.5 \\
\hline
\end{tabular}

by the intense territorial and aggressive activity observed in common bream males. A common bream male defended a territory including the spawning ground and attacked the other conspecific males and the heterospecific females. In such behavioural conditions, spawning was only observed on substrate but without male fertilization.

The similar egg release and mating numbers in hybridization experiments between common bream and silver bream, when mixing both sexes from each species, could be explained by a higher implication of silver bream males than that of common bream 


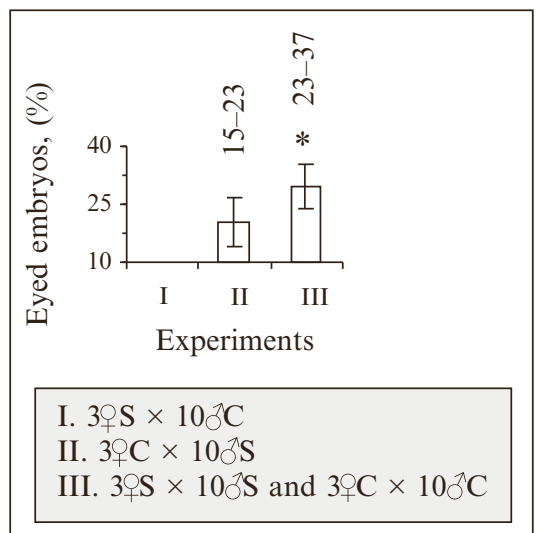

Figure 4. Mating success (\% eyed embryos) in hybridization experiments. Shaded insert: Roman numeral, experiment number; Arabic numeral, number of fish per sex in experiment; C, common bream; $\mathrm{S}$, silver bream; + , female; $\hat{O}$, male. Mean values of experimental duplicates; Vertical bars, standard deviations of experimental duplicates; Range, extreme values of four observations in two replications in each experiment; $n=400$, 407 and 382 eggs observed from four observations in two replications for experiments I, II and III, respectively; ${ }^{*}$, significant difference (FEP-test, $\left.p=0.003\right)$.

males, in both conspecific and heterospecific matings. The participating silver bream males were observed in all spawning activity with the conspecific females or the heterospecific females, the common bream. Territorial behaviour observed in common bream males was used to the establishment of a spawning site as reported by Pottle and Green (1979a, 1979b) in which all possible rivals were vigorously excluded and consequently, the small contribution to the reproduction among nonterritorial males of common bream. These observations could explained the small number of conspecific mating between common bream.

Moreover, the reproductive behaviours such as eggs release in females was already observed by several authors in natural spawning conditions (Shestopalova, 1978; Spivak, 1987; Fabricius, 1951; Poncin et al., 1996) and might not be exclusively explain the hormonal injection.

\section{Heterospecific matings}

The heterospecific matings were directly observed only between common bream females and silver bream males under two experimental conditions, hybridization experiments between common bream females and silver bream males and hybridization experiments between common bream and silver bream mixing both sexes from each species. Under this latter condition, a higher number of opportunistic heterospecific matings on the part of silver bream males than common bream males was observed. The smaller size of silver bream males could be an advantage for heterospecific matings because it increases the possibility for these males to thread between females or among fishes during conspecific spawning and the chance to be tolerated in the territory of the larger common bream males. For these males, small males such as the silver bream were not a danger; moreover, this species is nonaggressive and nonterritorial (Nzau Matondo 
et al., 2008b; Poncin et al., 2004). The large size difference between the common bream and silver bream on both sexes in experiments reflects in fact the growth difference between these two species in the wild. Indeed, the growth of silver bream is lower than common bream and does not exceed the size of $350 \mathrm{~mm}$, while this size is exceeded in common bream (Goldspink 1978a, 1978b; Volodin, 1979, 1988; Pivnicka and Cerny, 1996).

In a molecular study to detect the hybridization direction from natural hybrids of roach Rutilus rutilus L. $\times$ common bream and rudd Scardinius erythrophthalmus L. $\times$ common bream, the dominance of hybrid fishes with bream maternal origins was observed by Wyatt et al. (2006), a common point with the present study in which a large species, the common bream, as the female in heterospecific matings was observed to be dominant. The male bream are more aggressive and territorial than roach and rudd (Svardson, 1949; Fabricus, 1950; Diamond, 1985). For Wyatt et al. (2006), it may be possible that the nonterritorial roach or rudd males were mixed with female bream during spawning. The direction of hybridization among species in a natural population could be influenced by a number of factors including spatial, temporal, behavioural, physiological and stock composition, as reported by Pitts (1995).

In addition, heterospecific matings are frequent in fishes (Roselfield and KoddricBrown, 2003), especially in the Cyprinidae (Buth, 1984; Berrebi et al., 1993). Poncin et al. (1994) also observed heterospecific matings including a female Barbus barbus (L.) or Barbus meridionalis (Risso) with one to four males of the other species, explained by the intersexual vibrational communication during spawning behaviour in hybridization experiments between these two species conducted in aquaria.

\section{Eyed embryos rates}

The higher survival rate in experiments between common bream and silver bream mixing both sexes from each species than in experiments between common bream females and silver bream males could be attributed to the high level of conspecific mating between silver breams. However, this survival rate was much lower than that of conspecific crosses (Mamcarz et al., 2004; Urbányi et al., 2006; Nzau Matondo et al., 2007). No observations were made on the paternity of eyed embryos from hybridization experiments mixing both sexes from the two bream species and the hatching success in all experiments.

\section{Conclusion}

This study has demonstrated that the heterospecific matings of common bream and silver bream occurred between common bream females and silver bream males. On the basis of the size difference in these species, we can consider that in nature, natural hybridization could preferentially be accomplished between species with large females and other species with small males. The paternity of natural hybrids from these two breams could be particularly dominated by the silver bream males. 


\section{Acknowledgements}

The authors wish to thank Gilles Rimbaud for his technical assistance during spawner collections in Belgian Meuse River, Linda Northrup for editing the manuscript and two anonymous referees for their helpful comments.

\section{References}

Billard, R. (1997) Les Poisons d'Eau Douce des Rivières de France. Identification, Inventaire et Répartition des 83 Espèces. Lausanne, Delachaux and Niestlé, 192 p.

Berrebi, P., Cattaneo-Berriberi, G. and Le Brun, N. (1993) Natural hybridization of two species of tetraploid barbels : Barbus meridionalis and Barbus barbus (Osteichytes, Cyprinidae) in Southern, France. Biol. J. Linn. Soc., 48, 319-333.

Buth, D.G. (1984) Allozymes of the Cyprinid fishes. Variation and application. In: B.J. Turner (Ed.), Evolutionary Genetics of Fishes, pp. 561-590, Plenum Press, New York.

Diamond, M. (1985) Some observations of spawning by roach, Rutilus rutilus L. and bream, Abramis brama L. and their implications for management. Aquacult. Fish. Management, 16, 359-367.

Fabricius, E. (1950) Heterogenous stimulus summation in the release of spawning activities in fish. Rept. Inst. Freshwat. Res. Drottningholm, 31, 57-99.

Fabricius, E. (1951) The topography of the spawning bottom as factor influencing the size of the territory in some species of fish. Rept. Inst. Freshwat. Res. Drottningholm, 32: 43-49.

Freyhof, J. (1998) Riffle spawning white bream Abramis bjoerkna (Cyprinidae) in a regulated river: a case of unsuitable habitat choice? Ital. J. Zool., 65, 441-444.

Gillet, G. (1989) Le déroulement de la fraie des principaux poissons lacustres. Hydroécol. Appl., 1/2, 117-143.

Goldspink, C. R. (1978a) The population density, growth rate and production of bream, Abramis brama, in Tjeukemeer, the Netherlands. J. Fish Biol., 13, 499-517.

Goldspink, C. R. (1978b) A note on the dispersion pattern of marked bream Abramis brama released into Tjeukemeer, the Netherlands. J. Fish Biol., 13, 493-497.

Hänfling, B. and Brandl, R. (2000) Phylogenetics of European cyprinids: insights from allozymes. J. Fish Biol., 57, 265-276.

Huet, M. (1949) Aperçu des relations entre la pente et les populations piscicoles des eaux courantes. Schweitzerische Zeitschrift fur Hydrologie, 11, 332-351.

Katano, O. and Hakoyama, H. (1997) Spawning Behavior of Hemibarbus barbus (Cyprinidae). Copeia, 3, 620-622.

Kozlovskij, S. V. (1991) Observations of roach and bream spawning behaviour in the Saratov Reservoir. Vopr. Ikhtiol., 31, 876-878.

Maitland, P.S. (2005) A key to the freshwater fishes of the British Isles with notes on their distribution and ecology. Freshwat. Biol., 50, 920.

Mamcarz, A., Kucharczyk, D. and Kujawa, R. (2006) Reciprocal hybrids of tench Tinca tinca (L.) $\times$ bream Abramis brama (L.), and tench $\times$ carp Cyprinus carpio L., and some characteristics of their early development. Aquacult. Int., 14, 27-33.

Mills, C.A. (1991) Reproduction and life history. In: I. J. Winfield, and J.S. Nelson (eds). Cyprinid Fishes. Systematics, Biology and Exploitation, pp. 483-504. Chapman and Hall, London.

Nzau Matondo, B., Ovidio, M., Poncin, P., Kakesa, T.A., Wamuini, L. S. and Philippart, J.C. (2007) Hybridization success of three common European cyprinid species, Rutilus rutilus, Blicca bjoerkna and Abramis brama and larval resistance to stress. Fish. Sci., 73, 1136-1145.

Nzau Matondo, B., Ovidio, M., Poncin, P. and Philippart, J.C. (2008a) Sexual maturity, reproductive behaviour and fertility in the first-generation hybrids of Blicca bjoerkna L. $\times$ Abramis brama L. Cybium, 32, 286-289. 
Nzau Matondo, B., Ovidio, M., Philippart, J.C. and Poncin, P. (2008b) Mating patterns of first-generation hybrids of the roach, Rutilus rutilus (L.), and the silver bream, Blicca bjoerkna (L.). J. Ethol., 26, 179183.

Ombredane, D. and Baglinière, J.L. (1992) Les écailles et leurs utilisations en écologie halieutique (tissus durs et âge individuel des vertébrés). In: J.L. Baglinière, J. Castanet, F. Conand, and F.J. Meunier (Eds.), Tissus Durs et Âge Individuel des Vertébrés, pp. 151-193. Colloques et Séminaires ORSTOM - INRA, Bondy, France.

Philippart, J.C. (1971) Age et croissance de la vandoise, Leuciscus leuciscus (L.) dans l'Ourthe et la Berwine. Ann. Soc. Roy. Zool. Belg., 103, 61-77.

Philippart, J.C. (1981) Ecologie d'une population de vandoises, Leuciscus leuciscus (L.) dans la rivière Ourthe (Bassin de la Meuse, Belgique). Annls Limnol., 17, 41-62.

Philippart, J.C. (1989) Ecologie des populations de poissons et caractéristiques physiques et chimiques des rivières dans le bassin de la Meuse belge. Bull. Soc. géog. Liège, 25, 175-198.

Philippart, J.C. and Vranken, M. (1983) Atlas des poissons de Wallonie. Distribution, Ecologie, Ethologie, Pêche, Conservation. Cah. Ethol. Appl. 3 (1-2).

Pitts, C.S. (1995) Hybridization in the Fish Family Cyprinidae. PhD thesis, University of Hull, Kingston upon Hull, UK.

Pivnicka, K., Cerny, H., (1996) Poissons. Gründ ed., Paris, 304 p.

Poncin, P., Jeandarme, J. and Berriberi, P. (1994) A behavioural study of hybridization between Barbus barbus and Barbus meridionalis. J. Fish Biol., 45: 447-451.

Poncin, P., Philippart, J.C. and Ruwet, J.C. (1996) Territorial and non territorial spawing behaviour in the bream. J. Fish Biol., 49, 622-626.

Poncin, P., Binda, O., Termol, C., Chenuil, A., Rinchard, J., Kestemont, P., Berriberi, P. and Ruwet, J.C. (2000) Spawning tactics and reproductive success in two european cyprinids, the barbel (Barbus meridionalis) and the bream (Abramis brama): an overview. In: Proceeding of the 6th International Symposium on the Reproductive Physiology of Fish, Bergen, pp. 132-134.

Poncin, P., Termol, C., Nzau Matondo, B., Kestemont, P., Ylieff, M. and Philippart, J.C. (2004) Polyandrous spawning behaviour in Blicca bjoerkna (L.): an access to hybridisation with Abramis brama. In: Abstracts of oral presentations. XI European Congress of Ichtyology, Estonia, p. 58.

Pottle, R. A. and Green, J. M. (1979a) Territorial behaviour of the north temperate labrid, Tautogolabrus adspersus. Can. J. Zool., 57, 2337-2347.

Pottle, R. A. and Green, J. M. (1979b) Field observations on the reproductive behaviour of the cunner, Tautogolabrus adspersus (Walbaum), in Newfoundland. Can. J. Zool., 57, 247-256.

Roselfield, J. A. and Koddric-Brown, A. J. (2003) Sexual selection promotes hybridization betwen pecos pubish, Cyprinidon pecosensis and sheepshead minnnow, C. Variegatus. J. Evol. Biol., 16, 595-606.

Shestopalova, G.N. (1978) Reproductive biology of the Iriklinskoye reservoir bream (Abramis brama). J. Ichthyol., 17, 884-889.

Spillman, C.J. (1961) Faune de France, $n^{\circ}$ 65. Poissons d'eau douce. Paul Le Chevalier, Paris, 303 pp.

Spivak, E.G. (1987) Peculiarities of reproduction of white bream, Blicca bjoerkna, in Bys of Kakhovka Reservior. Vopr. Ikbtiol., 1, 101-105.

Svardson, G. (1949) Note on spawning habitats of Leuciscus erythrophthalmus (L.), Abramis brama (L.) and Esox lucius (L.). Rept. Inst. Freshwat. Res. Drottningholm, 29, 102-107.

Turner, G. (1986) Teleost mating systems and strategies. In: Pitcher, T. (ed.) The Behaviour of Teleost Fishes, pp. 253-274. Croom Helm, London, UK.

Urbányi, B., Szabó, T., Miskolczi, E., Mihálffy, S., Vranovics, K. and Horváth, Á. (2006) Successful fertilization and hatching of four European cyprinid species using cryopreserved sperm. J. Appl. Ichthyol., 22, 201-204.

Volodin, V. M. (1979) The influence of feeding and overwintering conditions on the duration of egg resorption and the development of the next generation of oocytes in the bream, Abramis brama, of Rybinsk reservoir. J. Ichthyol., 19, 147-150.

Volodin, V. M. (1988) Fecundity as a possible natural marker in the study of the intrapopulational structure and interpopulational differences of the bream, Abramis brama. J. Ichthyol., 28, 93-97. 
Wyatt, P.M.W., Pitts, C.S. and Butlin, R.K. (2006) A molecular approach to detect hybridization between bream Abramis brama, roach Rutilus rutilus and rudd Scardinius erythrophthalmus. J. Fish Biol., 69, 52-71.

Wheeler, A. (1969) Fishes of the British Iles and North-West Europe. Macmillan, London. 613 pp.

Wolter, C. (1999) Comparison of intraspecific genetic variability in four common cyprinids, Abramis brama, Abramis bjoerkna, Rutilus rutilus and Scardinius erythrophthalmus, within and between lowland river systems. Hydrobiologia, 394, 163-177. 